\author{
Borbala Obrusanszky \\ Ph.D. (in History), \\ Faculty of Social Sciences, \\ Karoli Gaspar University, Budapest, Hungary \\ borbala.obrusanszky@gmail.com
}

\title{
HUNS IN THE CAUCASUS - ACCORDING TO THE HUNGARIAN CHRONICLES
}

Abstract: The ancient Hungarian chronicles, written in the royal court, mention that ancestors of the Hungarians, namely Scythians and Huns, lived in the regions of Caucasus, and belonged to Nimrod, the first legendary king of the world. He could have been a real powerful king, because other nations of the region claimed relationship with him. Hungarians said that Nimrod's two sons, while chasing a magical stag, approached northward, kidnapped the daughters of the Alanian kings and settled down near the Meotic swamp. According to the Hungarian tradition, a large group of Savards/Sabirs left the Trans-Caucasus region and preserved their ancient culture and language as well. They lived there for a short period of time due to overpopulation. Huns gathered their elected leaders and decided to move westward to Pannonia, where they established the centre of the Hun state. Some scholars think that story was preserved as an epic and was sang by storytellers in the royal court.

From the late 19th century some German and Hungarian scholars questioned the authenticity of the Hungarian chronicles, but at the end of 2oth century the contemporary archaeological finds and local historical sources certified the accuracy of their reports. The modern sciences such as anthropology and DNA profiling also proved the ancestors of Hungarians lived in the regions of the Caucasus.

Keywords: Huns; Hungarians; Nimrod; Maeotis;Chronicon Pictum;the Caucasus; Savard.

\section{ГУННЫ НА КАВКАЗЕ - СОГЛАСНО ВЕНГЕРСКИМ ХРОНИКАМ}

\author{
Обрушански Борбала, \\ к.и.н., \\ Факультет общественных наук, \\ Университет Кароли Гаспара, Будапешт, Венгрия \\ borbala.obrusanszky@gmail.com
}

Аннотация. В древних венгерских хрониках, написанных при королевском дворе, упоминается, что предки венгров, а именно скифы и гунны, жили на Кавказе и происходили из рода Нимрода, первого легендарного правителя мира. Он действительно мог быть могущественным правителем, так как и другие народы региона утверждают о своем родстве с ним. Венгры говорят, что два сына Нимрода в погоне за магическим оленем забрели на север, «похитили» дочерей аланских царей и основали новое поселение на Меотийских болотах. Согласно венгерским преданиям, большая группа людей, Саварды/Сабиры, покинула Закавказье и сохранила свою культуру и язык. Они жили там непродолжительное время из-за перенаселения. Гунны во главе со своими вождями решили двинуться на запад к Паннонии, где основали центр государства Гуннов. Некоторые ученые считают, что эта история сохранилась в виде эпоса и пелась сказителями при королевском дворе.

С конца XIX века венгерские ученые сомневались в правдоподобности венгерских хроник, но в конце XX века археологические находки и местные исторические источники подтвердили сведения хроник. Современные науки, такие как антропология и генетические исследования, также подтвердили, что предки венгров жили на Кавказе.

Ключевые слова: гунны; венгры; Нимрод; Меотийские болота; Chronicon Pictum; Кавказ; Савард. 
Ancient chronicles ${ }^{1}$, written in the royal court of the Hungarian Kingdom, mentions some regions of the Caucasus, where the Huns, ancestors of the Hungarian royal clan, or "Turul", settled down and lived for a long time. Unfortunately, only few scholars have searched that period in the past hundred years. According to the local historical chronicles data and findings of the archaeological excavations, Huns appeared and settled down in the Caucasus region between the $2^{\text {nd }}$ and $4^{\text {th }}$ century $\mathrm{AD}$. In my paper, I summarize the most essential parts of the Medieval Hungarian royal chronicles like Chronicon Pictum $^{3}$ and Gesta Hungarorum by Kezai 4 . Both of them recorded the main events of Huns and Hungarians in the Caucasus. The Chronicon Pictum informs us about that:

„Cush begat Nimrod. He who led astray the seed of Noah so that they built a city and a tower against the Lord, as is told in the eleventh chapter of the Book of Genesis. Therefore it is said: He became a mighty one on the earth; for by his power he made others submit to him and he compelled them to perform against their will the prescribed labour.

Moreover, it is further said: He was a mighty hunter, that is, an oppressor of men, before the Lord, since nothing is hidden from His sight. Hence came the proverb that is the common or vulgar saying: Even as Nimrod. Later anyone, who was seen as an oppressor of men, would be called a second Nimrod or was likened to Nimrod. And the beginning of his kingdom was Babel, and his seed held the land as far as the seas of the ocean.

Whence it is clear for all to see that the words of those are not true who say that Hunor and Magor, the fathers of the Hungarians, were the sons of Nimrod. Nimrod did not live near the river Tanais, which is in the east, but he lived near the ocean.

Therefore, as the sacred Scripture and the holy doctors say, the Hungarians descended from Magog, the son of Japheth, who in the fifty-eighth year after the flood, came into the land of Evilah, and upon his wife Enee begat Magor and Hunor, from whom the Magyars and the Huns were named as St. Sigilbert, the bishop of Antioch says, in his chronicle of the eastern nations.

One day they went hunting, and in a deserted place a stag appeared before them, which they followed into the Maeotic marshes as it fled before them.

It disappeared again, and though they sought it for a long time, they couldn't find it anywhere. Having, at last, searched the marshes thoroughly, they found that the place was suitable for breeding herds. Therefore, they returned to their father and, having been granted his permission, they went with all their goods and chattels to the Maeotic marshes 5 to dwell and to raise their herds. The Maeotic region is located near Persia, and, except for a small neck of land, it is surrounded by the sea. It is wellwatered and rich in pasture, woods, fish, birds and beasts; it is difficult either to approach it or leave.

Having thus come to the Maeotic marshes, they stayed there for five years. Moving forward in the sixth year, they reached a deserted place, where they came upon the wives and sons of Bereka, without any of their menfolk, celebrating the feast of the tuba in their encampment. Quickly they fell upon them and carried them off with all their belongings to the Maeotic marshes. This was their first plunder raid since the flood. It happened that in that skirmish they seized two daughters of Dulo, ruler of the Alani, of whom one was married as a wife by Hunor and the other by Magor; and all the Huns, or Hungarians, sprang from these women.

While they were dwelling the Maeotic marshes, they began to grow into a more mighty nation, and the region could not contain them nor supply them enough"6.

\footnotetext{
${ }^{1}$ The first Hungarian chronicles are written by the royal priest since the second half of the 11th century. They were able to gather information about ancestors of Hungarians directly from the kings and their own storytellers or singers (the special name is regös), who sang epos of the Huns and Hungarians [1, p. 553-568]. The changes or new events were added gradually and the old chronicles disappeared, that's why only the latest versions remained. The most important Hungarian chronicles are Chronicon Pictum (1358) and Kezai Simon's Gesta Hungarorum (1283), Thuroczy's chronicle (1488) and Tarihi Üngürüs (1543). They all have preserved the ancient history of Huns and Hungarians from the Caucasus to the Carpathian basin [2; 3, p. 317-327].

${ }^{2}$ The Latin name for the royal clan is de genere Turul, meaning: the royal clan of Falcon.

${ }^{3}$ Chronicon Pictum is the greatest Hungarian chronicle written in Latin and decorated with pictures. It summarises the history of Hungary from the beginning until 1330.

${ }^{4}$ Kezai or Kezai Simon was a royal priest, who served Laslo IV or Laslo the Cuman (1272-1290). He also summarised the history of Hungarians from the earliest time until Laslo's reign. The name of the chronicle is Gesta Hungarorum or History of Hungarians [4].

${ }^{5}$ The eastern shore of the Azov Sea. It was the centre of Royal Scythians.

${ }^{6}$ Chronicon Pictum, 5 .
} 
According to another manuscript, written by Kezai Simon, who served as the royal priest for Laszlo (Cuman) IV7 , after the confusion of tongues at the tower of Babel, Nimrod moved to Evliath, which was a province of Persia, where his wife Eneth had given birth to two of his sons - Hunor and Magor. He had other sons from other wives and concubines. Hunor and Magor left the Persian province and moved northward, chasing the magical stag. They preserved their ancient languages, which was similar to the one Hun spoke, except that they spoke dialects as German Saxons and Thuringians did $\boldsymbol{s}$.

\section{Nimrod, the ancestor}

Having analyzed the texts of Hungarian chronicles, now we can focus on two topics: one is Nimrod's tradition; the second is the early presence of Huns in the Caucasus region. As it is well known, Nimrod - according to Bible9- was the first legendary king of the world. As Nimrod was considered to be a vicious person in Europe, nobody wanted to be originated from Him. Nobody in the Christian European world kept relationship with such a negative person, but Hungarians were proud of Him as an ancestor for centuries. Some Hungarian scholars thought that this fact was a strong evidence of Hungarian presence in the Caucasus. It means that Hungarians brought this cult from that place, where Nimrod was a well-known person and had a dynasty as well. Not only the Hungarian kings announced their kingship with Nimrod, but Georgian historical sources mentioned Nimrod as a historical figure and the king of that region as well. They had descendants, who ruled Georgia for years [5]. Besides that, Treasure of Caves [6] and the Moses Dasxuranci's The History of the Caucasian Albanians also mentioned him [7, p. 158].

\section{Huns in Hungarian sources}

Kezai's chronicle or Gesta Hungarorum referred to those Huns and Hungarians, who remained in the Trans-Caucasus region, too. They are Sabirs or Savards. Not only did the Hungarian chronicles mentioned them, but also the regional Byzantine, Arab, Persian, etc. historian sources. One of the first mentions about it is a Latin work. In the second half of the 4th century, Ammianus Marcellinus gave a concise description of the peoples who lived in the Caucasus and Maeotis region. He also said that there were a lot of peoples, unknown to them. He mentioned, for example, a known named group of people near the coast of the Black sea: the Sapirs. [8, XXII. 8]. They could have been Savards. This data could be an important proof that these people did not arrive to the South from Siberia [9] ${ }^{10}$ but - how József Thúry has already stated11 - they indeed had lived in the Caucasus all along [3, p. 321].

Jozsef Thury ${ }^{12}$ reconstructed the moving of Huns/Hungarians to the Caucasus region. According to him, Savards left the former land, or Trans-Caucasus and lived in the modern territories' of Western Azerbaijan-Eastern Armenia (which was the ancient Sakasena), where they had a powerful state until the end of the 14th century. The major part of Huns-Hungarians moved northward to the Darial pass and reached the Alans ${ }^{13}$. Finally, they chose the Maeotis swamp as their centre, where the royal Scythian lived and where commercial centre of Black Sea trade could be found. According to the Hungarian sources, when they overpopulated in the second half of the $4^{\text {th }}$ century, they decided to move westward, to Pannonia $^{\mathbf{1 4}}$, but not everyone left that place, lots of Huns-Hungarians remained in the ancient land ${ }^{\mathbf{1 5}}$.

The Hungarian chronicle says that Hunor and Magor, the leaders of Huns and Hungarians, chased a magical stag and it led them to a beautiful place, where they settled down. The story is common among Scythians and Huns as well16. The texts also mentioned that Huns and Hungarians leagued together with Alans. It was not a peaceful act, because the newcomer men robbed the Alanian girls. The

${ }^{7}$ Clan of the Hungarian kings in Latin is de genere Turul or royal clan of Turul. He reigned between 1272-1290. His mother was Cuman, that's why he got the nickname "Cuman."

${ }^{8}$ Kezai: Gesta Hungarorum. Part 3.

${ }^{9}$ Gen. 10.8-12.

${ }^{10}$ Czeglédy, 1955. He wanted to convince that Savirs/Sabirs migrated from Siberia.

${ }^{11}$ Jozsef Thury (1861-1906) was turkologist, historian. He was the best student of Vambery Armin, great traveler and scholar. Thury studied the Caucasus region, learnt Arabic, Persian, Turkic and other languages as well.

${ }^{12}$ Thury summarised the history of Savard Hungarians or Sabirs [3].

${ }^{13}$ According to the Hungarian sources, Alans had the king Dulo.

${ }_{14}$ The Carpathian-basin was an ancient homeland for steppe tribes. It seemed to be obvious, that Huns wanted to occupy it. The chronicle mentioned as Pannonia because the Romans occupied only that territory of the Carpathian basin. The Tarihi Üngürüs mentioned that a group of Huns, who already lived in Pannonia, sent an envoy to the Huns of Caucasus and requested them to attack Pannonia and liberate them from the Romans [10, p. 39].

${ }^{15}$ Chronicon Pictum 5.

${ }^{16}$ We can find that motif in Prisco's Getica and legend of St. Hubert, etc. 
venue probably happened in the North Caucasus - today's North Ossetia (Russia). Hungarian source, however, didn't date this event, but according to the text, it took place well before $373 \mathrm{AD}$. Both the Hungarian Chronicon Pictum and Jordanes said that Huns had begun to conquer Pannonia around $373^{17}$. Other historical sources, archaeological findings can specify the date of it.

\section{Foreign sources on Huns}

The local historical records are very important to be looked for early Huns in the Caucasus region. Gabor Balint, a great Hungarian scholar ${ }^{\mathbf{8}}$ was the first, who presented the earliest historical records about the Huns in the Caucasus in Hungary [11]. He stated that the Huns came from Asia. He also said that Huns did not suddenly appear in the Caucasus around the 370s but that they had already been there at the beginning of the 2nd century AD. Dionysius Periegetes ${ }^{19}$ mentioned the Huns in 117 AD: „....after the Unns the Caspians and then followed by the Albanians and Kaduses who lived in the mountainous region" [11, p. 31]. Claudius Ptolemy in his work titled Geographia wrote about the Huns, too. He drew their homeland precisely on the map: they dwelled between the Bastards and the Roxolans [11, P. 31 $]^{20}$. Written data on the Huns have multiplied from the 3rd century as at that time the Huns along with the members of the Armenian Arsacid dynasty overran Persia many times. Agathangelos reported on these events in his work on the life of Saint Gregory. Based on this, we can find out what role the Huns filled in the series of political events in the region [12]. It was recorded that in 227 $\mathrm{AD}$ Khosrov, ruler of Armenia together with the Iberians, Albanians and the Huns invaded Persia ${ }^{21}$. Later on, Tiridates (286-341) who was also Arsacid ran a campaign against Persians with Hun troops [12, p. 144]. In the era around $320 \mathrm{AD}$ Moses Khorenaci recorded the following: "Tiridates chased the Khazars and the Basils all the way to the country of the Huns"22. This late note confirms that the Huns had their own sovereign state in the Caucasus. Although the written records are fragmented and discontinuous, we can draw the conclusion from the data available that the Huns gradually spread their authority over the peoples living by the Sea of Azov and on the North coast of the Black Sea. The late antique Albanian and Armenian sources mentioned Huns as Honks. We can find Honagur, who was a local Hunnic king $\left[7\right.$, p. 63] ${ }^{23}$. But Georgian sources do not mention them at all. The reason for that is that Georgian chronicles are quite late from the 10-11th century $\mathrm{AD}$, and they confused steppe peoples as Turks, Khazars, etc. [13] ${ }^{24}$

As I have referred to this above, the Huns have multiplied in the foreground of the Caucasus, they have broken into the region beyond the Caucasus many times. Péter Váczy has also found historical data related to the Huns who lived in the Caucasus region in the middle of the 4th century AD. Their names appeared in a Persian campaign in $359 \mathrm{AD}$ when the Huns broke into Asia Minor. Between 363 and 373 they overran through the Caucasus into the Persian Empire and they then advanced all the

\footnotetext{
17 The text above.

${ }^{18}$ Balint Gabor (1844-1913) was the founder of Mongolian Studies in Hungary. He travelled to Russian Empire, where he collected folklore texts from Kazan Tatars, Kalmyks, Mongols. In 1895 he participated in a Caucasus expedition led by Jeno Zichy. He was appointed as a Head of the Department in Kolozsvar (today: Cluj) in 1893, where he taught Kabardian, Japan and other languages.

${ }^{19}$ He was a famous geographer of Caesar Hadrianus (117-138).

${ }^{20}$ Ptol. Geogr. III. 5. The Roxolans lived on the north of the Maeotis marshes and later moved to the region of the LowerDanube (Strabo. Geogr. VII. 3.17). They lived between the Tanais (Don) and the Borysthenes (Dniester) rivers between the 1st century BC and the 1st century AD.

${ }^{21}$ Agathangelos: History of St. Gregory and the Conversion of Armenia. Par. I: "Artashir, a Sassanian prince from the province of Stahr, put an end to the Parthian kingdom when he murdered the Parthian ruler Artavan. He united the Persian forces, and now they rejected Parthian sovereignty and chose him as their leader. Khosrov, king of the Armenians, was greatly distressed by that news and soon took up arms to avenge Artavan's death. He gathered Albanian and Georgian forces and called on the Huns to invade Persian territory. Khosrov and his armies ravaged the land, destroying towns and cities, trying to overthrow the Persian kingdom and wipe out its civilization. Even though the Parthians refused to help him, having attached them to Artashir, Khosrov was able to inflict devastating losses on the Persians. Then Khosrov returned victoriously to the Armenian city of Vagharshapat to celebrate his conquests and reward his soldiers, whom he showered with gifts and sent home. He also honored his family's ancestral worship sites, with white oxen, white rams, white horses and mules, and gave a fifth of all his plundered booty to the priests. He similarly honored the temples of the idol-worshipping cults throughout the land" (http://www.vehi.net/istoriya/armenia/agathangelos/en/Agathangelos.html).

${ }^{22}$ Based on L. Lukácsy's The History of Armenia, 1870, 144: "Whom Tiridates was chasing (the Khazar and the Basil) were chased up to the Huns' country". This sentence proves that at that time, that is to say, in the middle of the 4th century, there was a Hun, later on Hungarian residence there.

${ }^{23}$ The name Honagur is similar to Onogur/Hunnugur.

${ }^{24}$ The Chronicle mentioned Turks pp. 20, 28, 71, etc. It also mentioned Khazars pp. 18, 21, 25, etc.
} 
way to Edessa [14, p. 6]. L. Gmyrya who wrote a monograph on the Caucasian Huns, located the centre of the Hunnic Empire at the northwestern part of the Caspian Sea and noted that the territory of the Empire must have been much bigger [15, p. 9]. S. Botalov shares this view as he believes that the Caucasian Hun Empire must have been larger [16, p. 55].

\section{Other evidence}

To prove the early presence of the Huns in the Caucasus is difficult for many reasons. One reason is that the archaeological finds in the region are often regarded as the relics of local archaeological culture whereas in certain places the typical Hun polychrome style appears from as early as the 2nd century AD. Amongst the Alan finds in the Caucasus there are some semiprecious stone inlaid golden treasures that were also already found at the leaders of the Central Asian Scythian Empire, they were already there at the Kushan's and similar style objects turned up from the Mongolian Gol Mod 2 Hunnic tomb [17]. According to I. Zasetskaya, S. Botalov and other Russian archaeologists, the key to the westward migration of the Huns could be hidden in the Late Sarmatian and Alan archaeological material. It is very likely that the Huns already arrived with them in the foreground of the Caucasus and then the newly arriving peoples concluded alliances with local equestrian communities like Scythians, Sarmatians, Alans etc. They concluded a sworn brotherhood agreement; it was the most important act in the Eurasian steppe [18, p. 170-180].

It is also widely accepted by scholars, that the polychrome style (gold and almandine), which originated from Inner Asia, spread over Central Asia. Huns gave such jewellery to Gothic servants of Western Europe, and it appeared in the 5th century ${ }^{25}$.

The archaeologists gathered such findings from the above-mentioned territories but did not pay attention to the Georgian treasures. That's why nowadays the polychrome objects are listed as local Georgian finds. Treasure of Zghuderi, Kldeeti burials related the periods 2-3rd century AD. Armaziskhevi (Mtskheta) 2nd century AD burial contains some objects which are similar to Hunnic style too [20].

K. Smirnov thought that the presence of migrated Huns can be found in Sarmatian-Alanian tombs in the North-Caspian region in the 1st and 2nd century $\mathrm{AD}$ [21, p. 113]. I. Zasetskaya believes that these early Huns lived in the region between the Terek and Kuma rivers [22]. On the basis of this data we can state that Huns left their own traces in the Caucasus as well.

Anthropological remains also prove the presence of Huns in the region. In 2017 the result of an anthropological investigation was published, in which the scholars pointed out the similarities between skeletons of the Carpathian basin and Georgia during the Hunnic age. The authors [23] connected them via Alans and Sarmatians, but it is widely accepted that deformed skulls from the Caucasus to Western Europe belongs to Huns [24].

Analyzing the evidence above, we can confirm that the Hungarian Chronicle preserved well the existence of Huns in the Caucasus region. According to another historical data and archaeological finds, they arrived there around the 2nd century $\mathrm{AD}$ and left traces there. We can recognize their art in the course of the 2-4th centuries. When the main part moved westward, the Huns didn't disappear, but the centre of the Hunnic Empire passed through to Eastern Europe and later to the Carpathian basin.

\section{REFERENCES}

1. Szabó K. A királyi regösökről. In Századok. 1881: 553-568.

2. Hóman B. A magyar húnhagyomány és húnmonda. Budapest: Studium, 1925.

3. Thury J. A magyaroknak a szavarti aszfali neve. In Századok. 1897: 391-403.

4. Szabó K. (trans.). Kézai Simon: Gesta Hungarorum. Pest, 1862.

5. Rapp S.H. Studies in Medieval Georgian Historiography: Early Texts and Eurasian Contexts. Leuven: Peeters Publishers, 2003.

6. Budge W.A. (trans.). The Book of the Cave of Treasures: A History of the Patriarchs and the Kings, their Successors from the Creation to the Crucifixion of Christ. London: Forgotten Books, 2007.

7. Dasxuranci Movses. The History of the Caucasian Albanians. Translated by C.J.F. Dowsett London; New York: Oxford University Press: 1961.

8. Marcellinus Ammianus. Roman History. Translated by C. D. Yonge. London: Bohn's Classical Library, 1894.

9. Czeglédy K. A szavárd-kérdés Thury József előtt és után. In Magyar Nyelv. 1959: 373-385.

10. Blaskovics J. (trans.). Tarihi Üngürüs. Chronica of Hungarians. Budapest: Magvető, 1984.

11. Bálint G. A honfoglalás revíziója. Kolozsvár: Gombos Ferenc Könyvnyomdája, 1901.

${ }^{25}$ Childeric burial [19]. 
12. Lukácsy K. A magyarok őselei, hajdankori nevei és lakhelyei. Kolozsvár, 1870.

13. Metreveli R., Jones S. (eds.). Kartlis Tskhovreba. The Georgian Chronicle. Tbilisi: Artanuji Publishing, 2014.

14. Váczy P. A hunok Európában. In Attila és hunjai. Budapest: Magyar Szemle Társaság, 1940: 61-143.

15. Gmurya L. Land of the Huns at the Caspian Gates. Seaside Daghestan in the epoch of Great migration of the peoples. Makhachkala, 1995. - 228 p. (In Rus.).

16. S.G. Botalov. On the Issue of European and Asian Huns. In The Hun Forum. Origin and Identification Problems of the Eurasian Huns Culture. Collection of Scientific Papers. Chelyabinsk, 2013: 32-87. (In Rus.).

17. Erdenebaatar, D. Results and excavation of the Gol mod -II site. In Hsiung-nu Empire and the Study of Ancient Mongolian History. Ulaanbaatar: Mongolian Academy of Sciences. 2011.

18. Obrusánszky B. Attila, Európa ura. Barót: Tortoma, 2016.

19. Heather P. The Fall of the Roman Empire. A New History of Rome and the Barbarians. Oxford: Oxford University Press, 2006.

20. Lordkipanidze D. (ed.). Archaeological Treasury. Catalogue. Tbilisi: Georgian National Museum, 2011.

21. Smirnov K.F. Sarmatiam tribes of the Northern Caspaim/ In Kratkiye soobshcheniya Instituta arkheologii KSIA (Brief Communications of the Institute of Archaeology). Iss. 34. 1950: 97-114. (In Rus.).

22. Zasetskaya I.P. Nomadic culture of the South Russian steppelands (the end of the 4th - 5th centuries AD). Saint Petersburg: Ellips company, 1994. - 221 p.). (In Rus.).

23. Mayall P., Pilbrow V., Bitadze L. Migrating Huns and modified heads: Eigenshape analysis comparing intentionally modified crania from Hungary and Georgia in the Migration Period of Europe. In PLoS ONE. 12 (2): e0171064. 2017. Available: https://doi.org/10.1371/journal.pone.0171064.

24. Molnar M., Jason I., Szucs L., Szathmary L. Artificially deformed crania from the Hun-German Period (5th6th century AD) in northeastern Hungary: historical and morphological analysis. In Neurosurgical focus, 36 (4), 2014, 1-9. DOI: 10.3171/2014.1.FOCUS13466.

\section{СПИСОК ЛИТЕРАТУРЫ}

1. Szabó K. A királyi regösökről. In Századok. 1881. 553-568.

2. Hóman B. A magyar húnhagyomány és húnmonda. Budapest: Studium, 1925.

3. Thury J. A magyaroknak a szavarti aszfali neve // Századok. 1897. 391-403.

4. Szabó K. (trans.). Kézai Simon: Gesta Hungarorum. Pest., 1862.

5. Rapp S.H. Studies in Medieval Georgian Historiography: Early Texts And Eurasian Contexts. Leuven: Peeters Publishers, 2003.

6. Budge W.A. (trans.). The Book of the Cave of Treasures: A History of the Patriarchs and the Kings, their Successors from the Creation to the Crucifixion of Christ. London: Forgotten Books, 2007.

7. Dasxuranci Movses. The History of the Caucasian Albanians. Translated by C.J.F. Dowsett London; New York: Oxford University Press: 1961.

8. Marcellinus Ammianus. Roman History. Translated by C. D. Yonge. London: Bohn's Classical Library, 1894.

9. Czeglédy K. A szavárd-kérdés Thury József előtt és után. In Magyar Nyelv. 1959. P. 373-385.

10. Blaskovics J. (trans.). Tarihi Üngürüs. Chronica of Hungarians. Budapest: Magvető, 1984.

11. Bálint $G$. A honfoglalás revíziója. Kolozsvár: Gombos Ferenc Könyvnyomdája, 1901.

12. Lukácsy K. A magyarok őselei, hajdankori nevei és lakhelyei. Kolozsvár, 1870.

13. Metreveli R., Jones S. (eds.). Kartlis Tskhovreba. The Georgian Chronicle. Tbilisi: Artanuji Publishing, 2014.

14. Váczy P. A hunok Európában // Attila és hunjai. Budapest: Magyar Szemle Társaság, 1940. 61-143.

15. ГмыряЛ.Б.Страна гуннов у Каспийских ворот. Прикаспийский Дагестан в эпоху Великого переселения народов. Махачкала, 1995. - 228 с.

16. Боталов С.Г. О гуннах европейских и гуннах азиатских // Гуннский форум. Проблемы происхождения и идентификации культуры евразийских гуннов. Челябинск: ЮУрГУ, 2013. С. 32-87. - 640 с.

17. Erdenebaatar, D. Results and excavation of the Gol mod -II site // Hsiung-nu Empire and the Study of Ancient Mongolian History. Ulaanbaatar: Mongolian Academy of Sciences. 2011.

18. Obrusánszky B. Attila, Európa ura. Barót: Tortoma, 2016.

19. Heather P. The Fall of the Roman Empire. A New History of Rome and the Barbarians. Oxford: Oxford University Press, 2006.

20. Lordkipanidze D. (ed.). Archaeological Treasury. Catalogue. Tbilisi: GeorgianNationalMuseum, 2011.

21. Смирнов К.Ф. Сарматские племена Северного Прикаспия // Краткие сообщения Института истории материальной культуры. 1950. Вып. 34. С. 97-114.

22. Засецкая И.П. Культура кочевников южнорусских степей в гуннскую эпоху (конец IV-V вв.). СПб.: АО "Эллипс", 1994. - 221 с.

23. Mayall P., Pilbrow V., Bitadze L. Migrating Huns and modified heads: Eigenshape analysis comparing inten-tionally modified crania from Hungary and Georgia in the Migration Period of Europe // PLoS ONE. 12 (2): e0171064. 2017. Available: https://doi.org/10.1371/journal.pone.0171064.

24. Molnar M., Jason I., Szucs L., Szathmary L. Artificially deformed crania from the Hun-German Period (5th6th century $\mathrm{AD}$ ) in northeastern Hungary: historical and morphological analysis // Neurosurgical focus, 36 (4), 2014, 1-9. DOI: 10.3171/2014.1.FOCUS13466. 